\title{
Study of Various Storage Conditions on the Quality Attributes of Pre-treated Onion Paste
}

\author{
Prathyusha Vasipalli*, Pratibha Parihar, Priti Jain and K. C. Mahajan \\ Department of Food Science and Technology, College of Agricultural Engineering, JNKVV, \\ Jabalpur, 482004, Madhya Pradesh, India \\ *Corresponding author
}

\begin{abstract}
A B S T R A C T
\section{Keywords}

Onion paste, Pretreatment, Pyruvic acid, Quality parameter, Storage condition

Article Info

Accepted:

07 March 2020

Available Online:

10 April 2020

Pretreated onion pastes were evaluated for storage condition in this study. The pretreated onion paste was packed in glass containers and aluminum foil bags for storage period of 2 months at ambient condition and refrigeration condition $\left(4.4^{\circ} \mathrm{C}\right)$ for storage. Citric acid of $0.3 \%$ and sodiummeta bisulfate of $0.3 \%$ were used for pretreatment of the paste. The study was concluded that statistically highly significant differences were observed for moisture content, total soluble solids and pyruvic acid when stored at room temperature and refrigeration condition.
\end{abstract}

\section{Introduction}

Onion is one of major bulb crop grown in India which presently attracting attention of all persons due to rise in prices. Both immature and mature bulbs are used as vegetable and condiment. Onions not only provide flavor, they also provide important nutrients and health-promoting phytochemicals. It contains vitamin B and a trace of vitamin $\mathrm{C}$ and also traces of iron and calcium. As a culinary ingredient it adds to the taste and flavour in a wide range of food preparations and it is also used as a salad. Thus there is a steady increase in the demand for onion across the world.
The demand for the processed products is increasing day by day due to its convenience to handle and use. Onion can be processed into a wide variety of products. As per the estimate, approximately $6.75 \%$ of the onion produced is being processed. Besides fulfilling the constant demand of domestic population, India exports 13 to 18 lakh tons of onion annually worth around Rs. 2200 crores of foreign exchange revenue.

Onions are less perishable than many other vegetables; however losses are inevitable during storage. It has been estimated that 40 to $50 \%$ of the production never reaches to the 
consumers due to postharvest losses. The postharvest losses mainly consist of physiological weight loss, sprouting and decay. Onion cultivar differs in their ability to storage and this variation in the storage duration is either due to pre- and post harvest environmental conditions or due to the cultivar (Kopsell and Randle, 1997). Onions are stored mostly in shelters at ambient conditions. Some of the bulb characteristics like dry matter, total soluble solids, pungency and dry scale number are associated with the storage life of onion (Ko et al., 2002).

At producer level, the postharvest losses have been found maximum $(24.47 \mathrm{~kg} / \mathrm{q})$. The total post-harvest losses in onion at wholesale level were found to be $3.22 \mathrm{~kg} / \mathrm{q}$ and at retailer level it was $3.09 \mathrm{~kg} / \mathrm{q}$. And overall loss was reported as $30.87 \mathrm{~kg} / \mathrm{q}$. A large amount of losses (15.54 kg/q) also takes place during storage at farm. Across different stages, the losses have been found maximum at the grower level in onion (Sharma, 2016). By following proper pre-and post harvest management practices, storage losses can be reduced. Therefore, a study aimed at various storage conditions on the quality attributes of pre-treated onion paste.

\section{Materials and Methods}

\section{Raw materials}

Agrifound Light Red Varieties of onion were procured from Horticulture Farm, JNKVV, Jabalpur, MP, India. Analytical grade chemicals were used for analysis, which were available in laboratory of Food Science Department.

\section{Preparation of onion paste}

Matured and graded onion bulbs were manually selected and cleaned by removing the outer skin and roots with the help of knife.
Then, they were chopped and passed through crusher for fine onion paste. Onion paste was divided into lots for mixing of two preservatives i.e. citric acid of $0.3 \%$ and sodium-meta bisulfate of $0.3 \%$.

\section{Storage conditions}

The pretreated onion paste was packed in glass containers and aluminum foil bags for storage period of 2 months at ambient condition and refrigeration condition $\left(4.4^{\circ} \mathrm{C}\right)$ for storage. All samples were analyzed for quality measurement after $0,15,30,45,60$ days. The data obtained from various experiments were statistically analyzed. Pretreated samples were also compared with control sample at each storage interval.

\section{Physico -chemical analysis of onion paste moisture content}

The moisture content of onion paste was determined according to the method of A.O.A.C (1992).

\section{Total soluble solids}

The total soluble solids (TSS) of samples were measured at room temperature by Hand refractometer. $20{ }^{\circ} \mathrm{C}$ temperatures was set as a standard.

\section{Pyruvic acid}

Pyruvic acid of the sample was determined by using standard pyruvic acid method as given by Schwimmer S and Weston WJ (1981).

\section{Microbial examination}

Microbiological analysis was done by pour plate method described by ICMSF (1992). All samples were analyzed for the populations of bacteria and total mould load. Results were expressed by using colony counter. Number 
of colonies were counted and expressed as per $\mathrm{g}$ or $\mathrm{ml}$ of sample.

\section{Sensory evaluation}

The sensory quality characteristics i.e. overall acceptability of the products such as colour and appearance, taste, texture, flavour were evaluated by panel of 15 participants including faculty member and students of department using nine point hedonic scale as described by Amerine et al., (1965).

\section{Results and Discussion}

Effect of storage conditions and storage periods on the moisture content of onion paste

The influences of different storage conditions and storage periods on the moisture content of onion paste are shown in figure 1. Maximum moisture content was found $86.70 \%$ in $0.3 \%$ sodium meta bi sulfite treated Bhima Super onion var. paste at initial stage of storage. Minimum moisture content was found $(85.41 \%)$ in control sample after 60 days of storage. Glass containers were statically superior to aluminum foil bags for all treated onion paste during storage of onion paste. Significant difference was found between moisture content and storage conditions for onion paste during different storage periods.

Moisture content decreased with increases the storage period in all treated onion paste. Chemical treatments affected the moisture content of onion paste significantly where control onion paste samples had the highest moisture content compared to the treated ones during storage. This might be due to permeability to water vapour. Similar finding was reported by Javeed et al., (2015) about effect of quality parameters of developed ginger garlic paste during storage.

Effect of storage conditions and storage periods on the total soluble solids of onion paste

It is cleared from figure 2 that TSS content of onion paste varieties decreased during storage period in all processing variables of onion paste. Maximum TSS content was found to be $13.80^{\circ}$ Brix in control sample kept in glass container at initial stage of refrigeration storage, whereas minimum TSS was found to be $11.70^{\circ}$ Brix in control sample at 60 days of storage. The decrease in total soluble solids might be due to activity of fermentation. Similar finding reported by Ramadevi et al., (2010) for changes in quality and chemical parameter of onion bulbs during storage.

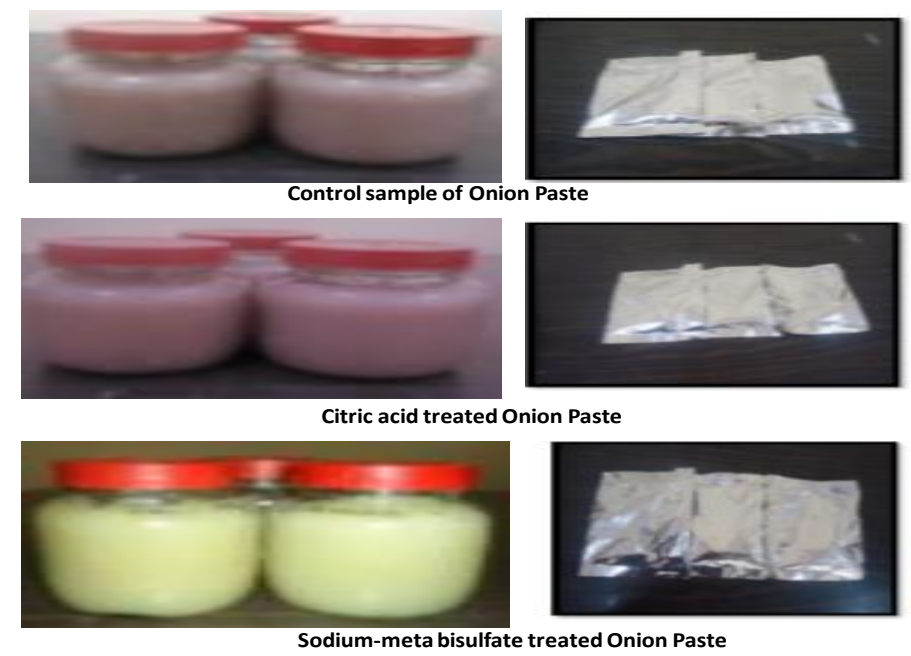


Fig 1: Effect of various storage conditions on moisture content of onion paste

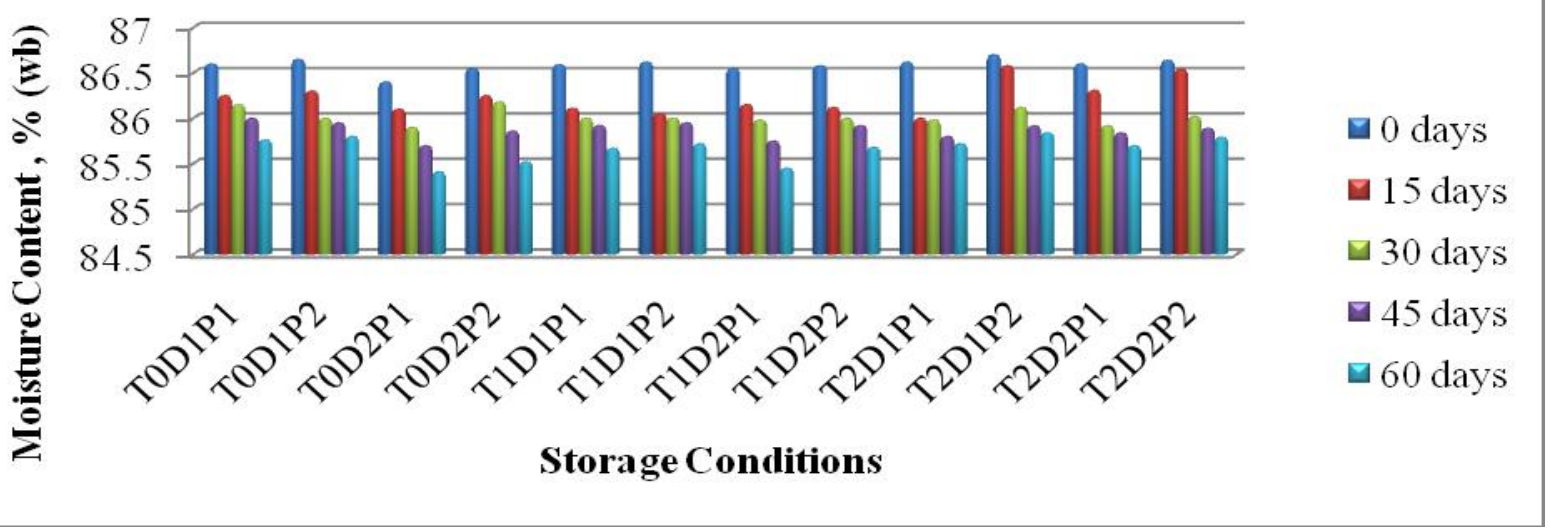

$\mathrm{T} 0=$ Control, $\mathrm{T} 1=$ Citric acid $0.3 \%, \mathrm{~T} 2=$ Sodium meta bi sulfite $0.3 \%, \mathrm{D} 1=$ Refrigeration, $\mathrm{D} 2=$ Room storage, $\mathrm{P} 1=$ Glass containers, P2=Aluminum Foil bags

Fig 2: Effect of various storage conditions on total soluble solids of onion paste

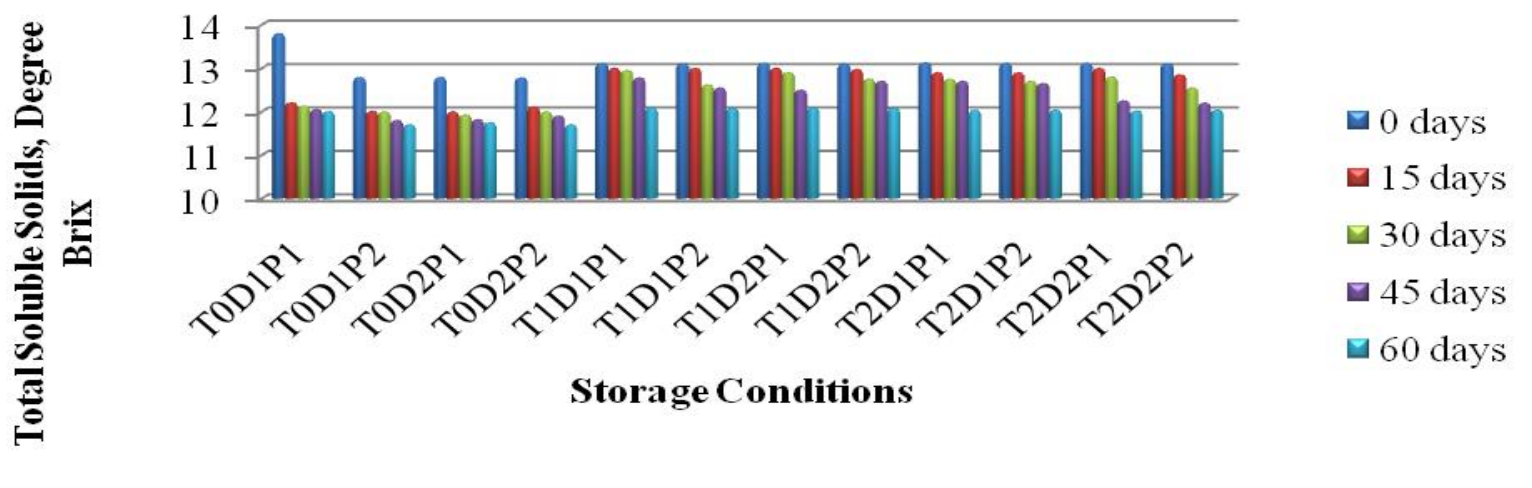

Fig 3: Effect of various storage conditions on pyruvic acid of onion paste

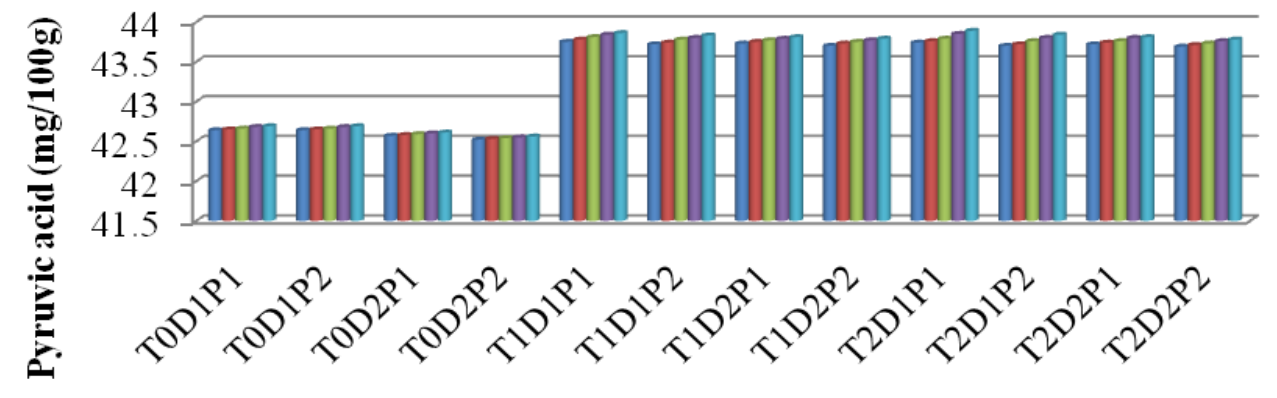

0 days

- 15 days

30 days

$\square 5$ days

60 days

Storage Conditions 

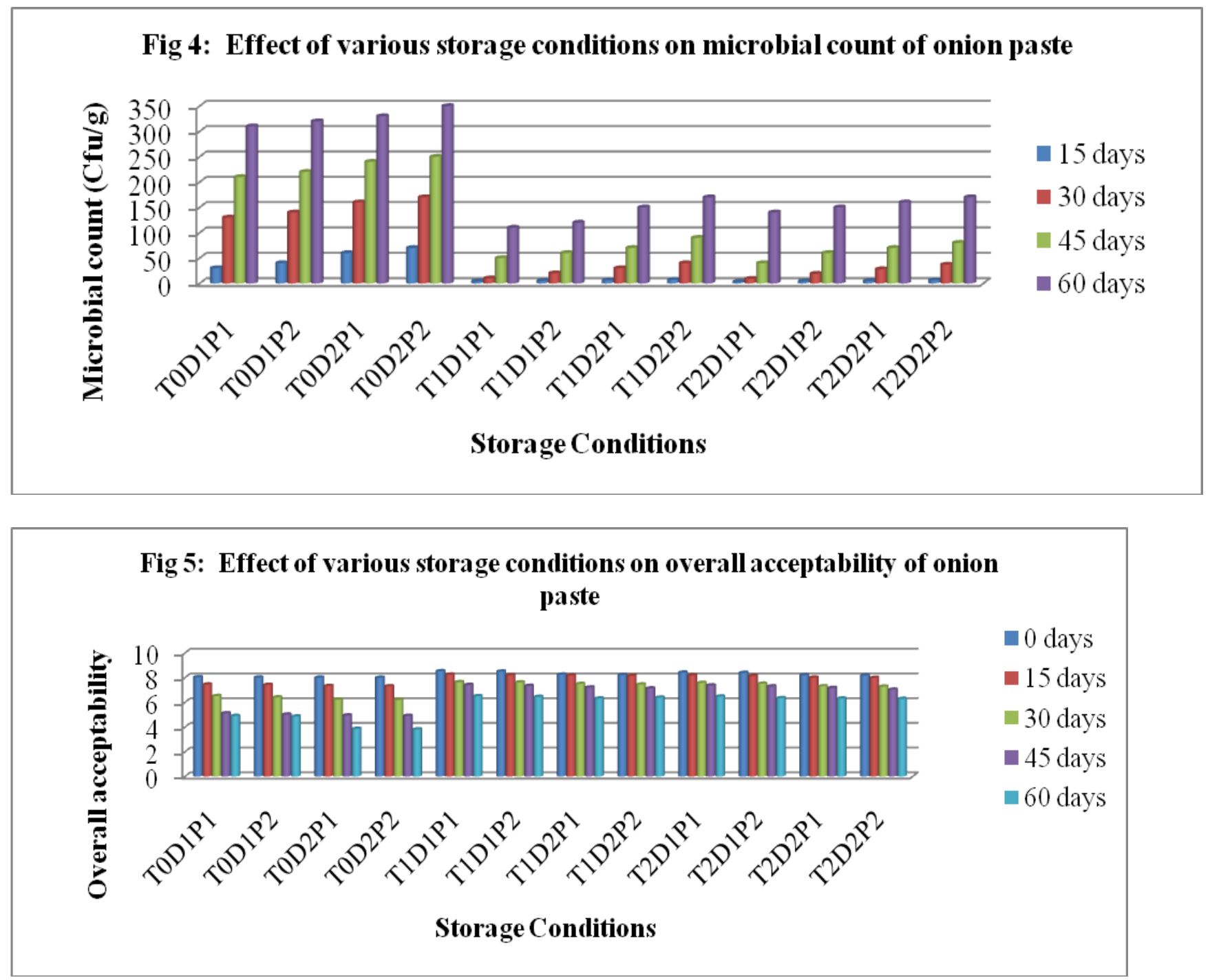

Effect of storage conditions and storage periods on the pyruvic acid content of onion paste

Pyruvic acid content slightly increased with increases the storage periods (Figure.3). Maximum pyruvic acid content was found to be $43.89 \mathrm{mg} / 100 \mathrm{~g}$ in sample treated with sodium- meta bi sulfite kept in glass container at 60 days of refrigeration storage, whereas minimum was found to be $42.52 \mathrm{mg} / 100 \mathrm{~g}$ in control sample kept in aluminum foil bags at initial stage of room storage. Pyruvic acid content was statically at par in all treated stored onion varieties in packaging materials and storage conditions of onion paste. Glass containers and refrigeration storage condition were significantly superior to the aluminum foil bags and ambient condition for stored onion paste varieties. Significant difference was found in pyruvic acid content with respect to processing variables during storage. Pyruvic acid content increased with respect to the fresh onion paste during the storage at different processing variables of paste. During storage the pyruvic acid content also varied with changes in dry matter varieties and sulfur nutrition. Similar findings reported by Sharma and Yong (2016) in the study of effect of different storage temperature on chemical composition of onion. 
Effect of storage conditions and storage periods on microbial count of onion paste

Microbial count of onion paste varieties presented in figure 4. Microbial load increased with increases the storage periods. Maximum number of microbial counts was found to be $3.5 \times 10^{2} \mathrm{cfu} / \mathrm{g}$ in control sample kept in aluminum foil bags at 60 days of room storage period, whereas minimum (zero) or microbial free was found in all preservatives treated onion varieties at initial stage of storage. Microbial count increased with increasing the storage period of onion paste varieties. The data showed that among all the storage conditions, onion paste treated with citric acid kept in the refrigeration condition in glass containers were significantly superior to control growth of microbes than other storage conditions. This might be due to acidic media of paste. Similar finding reported by Topno et al., (2013) for microbial evaluation of ginger garlic paste in retort pouches.

\section{Effect of storage conditions and storage periods on overall acceptability of onion paste}

The variation in overall acceptability of onion paste varieties observed in various storage conditions during storage data presented in figure 5. It indicates that the rank for maximum overall acceptability of onion paste varieties was found to be 8.53 in ample treated with citric acid kept in glass container at initial stage of the refrigeration storage, whereas minimum rank (3.82) was found in control sample kept in aluminum foil bags at 60 days of room storage period according to hedonic scale. Acceptability of stored onion paste decreased with increased in storage period. Onion paste treated with citric acid at refrigeration condition was significantly superior to other treatments. This might be due to changes of colour, flavor and texture of onion paste. Similar finding was explained by Jasim Ahmed et al., (2001) for physicochemical and storage characteristics of garlic paste.

In conclusion the results were concluded onion paste treated with citric acid of $0.3 \%$ and sodium-meta bisulfate of $0.3 \%$ were considered the best for 60 days of storage in glass container at refrigeration condition, but control sample was not accepted for 60 days of storage. Hence, low cost onion paste could be prepared for minimizing the post harvest losses of onion bulbs and time saving for preparation of vegetables. Efforts should be made for transfer of technique to household women for cottage level.

\section{References}

Amerine MA, Pangborn RM and Rosseier EB. 1965. Principle of Sensory Evaluation of Food. Academic Press, New York and London p5.

AOAC. 1992. Official methods of analysis. 16th edition, Association of Official Analytical Chemist Inc. Arlington VA. Chemists, Washington DC.

ICMSF. 1992. Microorganisms in foods and their significance and methods of Enumeration, 2nd Ed. International commission on microbiological specifications for foods. University of Toronto press, Toronto, Canada.

Jasim Ahmed and Pawanpreet and Shivhare US. 2001. Physico-chemical and storage characteristics of garlic paste. Journal of Food Processing and Preservation, 25:15-23.

Javeed Akhtar, Omre PK and Mohd Aftab Alam. 2015. Effect on quality of developed ginger-garlic paste during storage. IJAPSA, 01(8) e-ISSN: 23945532, p-ISSN: 2394-823x.

Kavita Sharma and Yong Rok Lee. 2016. Effect of different storage temperature 
on chemical composition of onion (Allium cepa L.) and its enzymes. J Food Sci Technol., 53(3):1620-1632.

Ko, S.S., Chang, W.N., Wang, J.F., Cherng, S.J. and Shanmugasundaram, S. 2002. Storage variability among short day onion cultivars under High Temperature and High Relative Humidity, and its Relationship with Disease Incidence and Bulb Characteristics. J. American Soc. Horti. Sci. 127: 848-54.

Kopsell, D.E. and Randle, W.M. (1997). Onion cultivars differ in pungency and bulb quality changes during storage. HortSci. 32: 1260-63.

Ramadevi, Ramakrishna BM and Karthik MN. 2010. Change in quality and chemical pararmeters of onion (Allium capa L.) bulbs during storage period, Asian J. Hort., 5 (2): 379-382.

Schwimmer S and Weston WJ. 1981. Enzymatic development of pyruvic acid in onion as a measure of pungency. J. Agric Food Chemistry 9: 301-304.

Sharma SwatiI (2016). Economic Analysis of Post Harvest Losses in Onion in Jodhpur District of Rajasthan International Journal of Research in Business Management Vol. 4, Issue 3, Mar 2016, 119-124.

Topno PN and Vinothini, Shilpa, Vishalakshi, Satish, pushpa and Madhava Naidu. 2013. Ginger-garlic paste in retort pouches and its quality. Journal of Food Process Engineering ISSN17454530 .

\section{How to cite this article:}

Prathyusha Vasipalli, Pratibha Parihar, Priti Jain and Mahajan, K. C. 2020. Study of Various Storage Conditions on the Quality Attributes of Pre-treated Onion Paste. Int.J.Curr.Microbiol.App.Sci. 9(04): 533-539. doi: https://doi.org/10.20546/ijcmas.2020.904.064 